DOE/ID/13040-21

\title{
GEOTHERMAL DIRECT-HEAT UTILIZATION ASSISTANCE
}

\author{
Quarterly Progress Report
}

Apri1 - June 1993

\section{DISCLAIMER}

This report was prepared as an account of work sponsored by an agency of the United States Government. Neither the United States Government nor any agency thereof, nor any of their employees, makes any warranty, express or implied, or assumes any legal liability or responsibility for the accuracy, completeness, or usefulness of any information, apparatus, product, or process disclosed, or represents that its use would not infringe privately owned rights. Reference herein to any specific commercial product, process, or service by trade name, trademark, manufacturer, or otherwise does not necessarily constitute or imply its endorsement, recommendation, or favoring by the United States Government or any agency thereof. The views and opinions of authors expressed herein do not necessarily state or reflect those of the United States Government or any agency thereof.

Work Performed Under Contract No. DE-FG07-901D13040

$$
\begin{aligned}
& \text { Prepared for the } \\
& \text { U.S. Department of Energy } \\
& \text { Under DoE Idaho Operations Office } \\
& \text { Sponsored by the Office of the Assistant Secretary } \\
& \text { for Energy Efficiency and Renewable Energy } \\
& \text { Office of Industrial Technologies } \\
& \text { Washington, D.C. }
\end{aligned}
$$$$
\text { Prepared by }
$$$$
\text { Geo-Heat Center }
$$$$
\text { Oregon Institute of Technology }
$$$$
\text { Klamath Falls, OR } 97601
$$ 


\section{DISCLAIMER}

This report was prepared as an account of work sponsored by an agency of the United States Government. Neither the United States Government nor any agency Thereof, nor any of their employees, makes any warranty, express or implied, or assumes any legal liability or responsibility for the accuracy, completeness, or usefulness of any information, apparatus, product, or process disclosed, or represents that its use would not infringe privately owned rights. Reference herein to any specific commercial product, process, or service by trade name, trademark, manufacturer, or otherwise does not necessarily constitute or imply its endorsement, recommendation, or favoring by the United States Government or any agency thereof. The views and opinions of authors expressed herein do not necessarily state or reflect those of the United States Government or any agency thereof. 


\section{DISCLAIMER}

Portions of this document may be illegible in electronic image products. Images are produced from the best available original document. 
1.0 Project Summary: April - June 1993

1.1 Technical Assistance. GHC staff provided assistance to 60 requests from 19 states. A breakdown of the requests according to application include: space and district heating (5), geothermal heat pumps (10), greenhouses (2), aquaculture (2), industrial (5), equipment (8), resources (9), electric power (3) and other (16).

1.2 R \& D Activities. Progress is reported on: 1) Evaluation of Lineshaft Turbine Pump Problems, 2) Geothermal District Heating Marketing strategy, and 3) Greenhouse Peaking Analysis.

1.3 Technology Transfer. Two presentations and one tour were conducted, and three technical papers were prepared. The GHC Quarterly Bulletin was sent to $1703 \mathrm{U} . \mathrm{S}$. subscribers and to 298 foreign addresses. There were 31 volumes added to the library and information was disseminated to 19 requests.

1.4 Geothermal Progress Monitor. Progress reports include: 1) USGS Forum on Mineral Resources, 2) Renewable Energy Tax Credits Not Working as Congress Intended, Geothermal Industry Tells House Panel, 3) Geothermal Drilling ok'd Near Fields, 4) Newberry Pilot Project, and 5) Low-Temperature Geothermal Resources in Nevada.

1.5 GHC staff that worked on the project during third quarter included: P. Lienau 59\%, G. Culver 95\%, K. Rafferty 100\%, Donna Gibson $62 \%$, and $J$. Lund donated 40 hours to the project.

\subsection{Technical Assistance}

Geo-Heat Center staff provided technical assistance to the following during April - June 1993:

Name

2.1 Alvin S. Hanzlik $15660 \mathrm{C}$ Miller Road Plano, IL 60545

2.2 Richard Parkes National Drying Machinery $\mathrm{Co}$. 1290 Hormig Road Philadelphia, PA

\section{Nature}

GHP. Discussed geothermal heat pumps technology including groundwater and ground-coupled applications. Provided information on utility incentives. Two contacts in Illinois were provided to aid in design and installation of $a$ GHP system $(4-1-93)$.

Industrial. Discussed using geothermal energy for a food dryer. National Drying Machinery Co. is bidding on a geothermal food dryer to be installed somewhere in Nevada (secret). A $305^{\circ} \mathrm{F}$ geothermal resource is available for the project. Discussed corrosion, scaling, materials, heat exchangers, etc. sent several chapters from the Direct Use Engineering and Design Guidebook (4-1-93). 
2.3 Robin McGuire 846 Wright Avenue Alliance, $\mathrm{OH} 44601$

$\begin{array}{ll}2.4 & \text { Rich Estabrook } \\ \text { BLM } \\ \text { Ukiah, CA }\end{array}$

2.5 John Cogar Lakeview, OR

\subsection{Alfred Truesdell 700 Hermosa Way Menlo Park, CA 94025}

2.7 Will Bunker

P.O. Box 9

Lake Village, AR 71653

2.8 Pat Lilly EBASCo Environmental Services, Inc. sacramento, CA

2.9 Doug Sherman Parks \& Recreation Desert Hot Springs, CA

2.10 Jeff Henkleman SEA Engineers Sparks, NV

2.11 Kathy Manger Meridian Alexandria, VA
GHP. Provided information on comparisons of geothermal heat pumps with conventional systems and list of manufacturers. Discussed domestic water heating using a desuperheater vs demand-type heat pumps $(4-2-93)$.

Resource. Discussed royalty billing considerations for a geothermal greenhouse operation at Lightning Dock, New Mexico. Requested information of flow meters and metering in general. Discussed problems and provided names of instrument manufacturers (4-3-93).

Electric Power. Discussed status and condition of binary units of Jack Wood's project north of Lakeview. The discussion included operation (very short), refurbishing done by Barber-Nichols (heat exchangers and controls) and ORMAT (turbines) units. The units are to be auctioned off by the city (4-5-93).

GHP. Requested international contacts on geothermal heat pumps. Provided: Lund University, Sweden; Institute of Geophysics, Switzerland; and Ontario Hydro, Canada (4-5-93).

Aquaculture. Discussed heat loss from ponds and provided spreadsheet on calculating pond heat loss. Also, discussed greenhouse heating using geothermal fluids $(4-6-93)$.

Equipment. Discussed metering of geothermal in general and problems due to scaling, corrosion and installation (4-793).

Resources. Requested information on resources at parks and city golf courses for potential pool heating, etc. Discussed resources at the north and south parts of the town. Referred to Kristy Hunter and Tim Boardman of DOG for more specific information (4-9-93).

Resource. Requested thermal conductivity values for various types of soils, which were provided $(4-12-93)$.

General. Assisted with a calculation of direct-use growth for a trend analysis $(4-13-93)$. 
2.12

Don Proteous

U.S. General Accounting office San Francisco, CA

2.13 Wayne Rasmussen Coeur d'Alene, ID

2.14 Elon Yurwit

2.15 Stephanie Vujruch Sportsman's Lodge Box 305

Ennis, MT 59729

2.16 Steve Groseclose Argonne Nat. Lab Washington, D.C.

2.17 Jim Healey AWS Albany, NY

2.18 Doug Adkins Consulting Engineer K. Falls, OR
2.19
David Collar 15185 Vista Drive Caldwell, ID 83605

General. Working on an evaluation of geothermal direct-use and electric power in terms of resource base, sustainability, geothermal heat pumps, etc. Provided information on direct-use database and low-temperature resource assessment program $(4-13-93)$.

Greenhouses. Looking for a greenhouse operation for a site in western Idaho on the Snake River, which has a spring fed pond, thermal spring at $90 \mathrm{gpm}$, Well-1 flows $100 \mathrm{gpm} 130^{\circ} \mathrm{F}$ and Well-2 flows 80 gpm $85^{\circ} \mathrm{F}$. Site consists of 40 acres with 20 acres suitable for development $(4-13-93)$.

Resource. Looking for a geothermal resource for a resort development. Earlier we had suggested Keough Hot Springs which apparently has some legal/personal problems. Discussed in general several hot springs in Utah and Colorado (4-15-93).

Resource. Faxed Thexton's well logs (956 ft) about 1 mile from site and $\mathrm{log}$ of well at sportsman to $500 \mathrm{ft}$. Wanted to know if she should go ahead and deepen. Logs look similar; but, information on geology is sketchy. Referred to Bob Bergantino, MT Mines and Geology (4-15-93).

Resource. Requested number of direct-use injection wells. Read list over the phone including the larger heat pump injection wells the GHC knows of (4-15-93).

General. Working on a study of potential for electric power production and directuse in upstate New York. Needs a list of candidates to do the work--a list of four companies with expertise in the geological area were supplied (4-19-93).

Resource. Discussed injection well disposal problems at Alturas, CA schools, including routes, amount of water, temperature, etc. City has requested Adkins engineers to look into possibility of using geothermal for heating city pools $(4-20-93)$.

Electric Power. Requested information on binary power plants, direct-heat applications and geothermal heat pumps, which was provided (4-20-93). 
2.20 Manville B. Rose 14552 Mayfield Road Huntsburg, OH 44046

2.21 Warren Nelson RTD Hydro Project Boise, ID

2.22 Ted Combis 1034 Leme Road Redding, CA 96003

2.23 Bob Brennan

Bonanza, OR

2.24 Michael S. Wilson 6361 Arapahoe Drive Evergreen, CO 80439

2.25 Kevin Taylor 1275 Taylor Ogden, UT 84404

2.26 Paul Hirsch Argonne Nat. Lab 9700 S. Cass, Bldg. 214 Argonne, IL 60439

2.27 Gary Thayer LANL Los Alamos, NM

2.28 Steve Rubin NREL 1617 Cole Blva. Golden, Co 80401
GHP. Requested information on groundcoupled heat pumps since the current groundwater system does not supply enough flow. Provided a range of costs for vertical (\$700-\$1000/ton) and horizontal ( $\$ 350$ - $\$ 500 /$ ton), and literature on the types of systems (4-21-93).

Electric Power. Discussed power generation locations. Building proprietary binary equipment of $1-2 \mathrm{MW}$ to use lowtemperature resources (4-23-93).

space Heating. Building a light manufacturing plant in $\mathrm{K}$. Falis. Wants to use geothermal if available. Discussed nearest wells which were about $4700 \mathrm{ft}$ distance. Sent geologic information and information on wells. Property on Market street, also being considered, has a good chance of hot water (4-26-93).

GHP. Wants to install a groundwater heat pump. Discussed well (existing) and disposal options $(4-29-93)$.

General. Discussed $440^{\circ} \mathrm{F}$ well in the Piceance Basin of colorado and referred to the Colorado Geological Survey. Also, discussed possibility of working in the geothermal industry and referred to several companies (4-29-93).

General. Discussed what the GHC does and renewable energy in general. Provided literature on geothermal direct-use (430-93).

GHP. Discussed geothermal heat pump technology and sent listing of GHP manufacturers. Referred to handbook by steve Kavanaugh, University of Alabama (5-4-93).

Industrial. Discussed arying of coffee beans at Mirravalles, El Salvador. A proposal for a pilot plant is being submitted (5-5-93).

GHP. Discussed geothermal heat pump technologies and solar assisted heat pumps. Provided manufacturers list for GHP (5-693). 
2.29 Shawn Lockran

Clackamas County

Clackamas, OR

2.30 Louie Templeton

vtility supt.

city hall

$66 \mathrm{~N}$. Lassen Street

Susanville, CA 96130

2.31 Earl Kent

K. Falls, OR

2.32 Frank Monastero

Commander

Naval Air Weapons

station

Geothermal Program office

China Lake, CA 935556001

2.33 Donald Yamada

U.S. General Accounting office

301 Howard Street

San Francisco, CA 94105

2.34 Peter Warnken

Decision Analysis

Corp.

1600 Spring Hill Road

Vienna, VA 22182

2.35 James $v$. Vantine

Consulting Geothermal

Geologist

97 Cottontail

windsor, CA 95492

2.36 Don Combs

Commander

American Legion Post 8 K. Falls, OR
Resource. Requested information on wells near Government Camp. Discussed snow melt systems and well information on GHC files. Referred to Oregon Department of Geology and Mineral Industries (5-10-93).

Equipment. Discussed and provided design for a geothermal depth/temperature well logger. Provided specs. on YSI 44014 thermistor and readout instrument (5-1193).

Resource. Requested data on well at 719 Eldorado for inheritance, which was provided (5-11-93).

General. Provided "Geothermal Direct Use Engineering and Design Guidebook" for renewable and energy conservation possibilities at the facility. Also, sent information on the GHC technical assistance program $(5-13-93)$.

General. Spent 1.5 days at the GHC discussing the potential of geothermal district heating, low-temperature resource assessment and geothermal heat pumps. Provided tour of OIT, city, Liskey Farms and residence $(5-18-93)$.

General. Discussed direct-heat applications of geothermal and temperature ranges. Provided literature on direct uses $(5-20-93)$.

General. Discussed geothermal direct-use development, potential and provided back issues of the GHC Bulletin (5-20-93).

District Heating. Preliminary review for connection of the Legion building to the city's geothermal district heating system. Conversion of the existing system is estimated to cost $\$ 11,000$ and a share of the cost of extending the lines. Based on data from the gas company, weather normalized, annual costs for gas amount to $\$ 765$. Assuming a city geothermal rate of $50 \%$ of natural gas, the savings would amount to $\$ 380 / \mathrm{yr}$. This figure does not 
2.37 Fr. Dreisbach

Sacred Heart Church

429 North 8 th Street

K. Falls, OR 97601

2.38 Eric Womer

Wormser Scientific

Assoc.

66 Doral Farm Road

Stanford, CT 06902

2.39 John Skaggs

229 Malabu Drive

Lexington, KY 40502

2.40 Kelly Mulville 33800 Highway 550

Durango, Co 81301 compare favorably with the capital costs, which suggests it is not economically feasible to connect the building at this time $(5-27-93)$.

District Heating. Preliminary review for connecting the sacred Heart Church to the city's district heating system. The cost for converting the buildings (sanctuary, gym, parish hall) is estimated to be $\$ 30,000$ including engineering and contingency allowances. In addition, a fee would be assessed for connection to the extension line, estimated at $\$ 8,400$. Based on average gas heating costs of $\$ 4,800 /$ year and assuming a city geothermal rate of 50\%, the resulting savings would be $\$ 2,400 /$ year. A $12 \%$ increase for natural gas is currently before the PUC (5-27-93).

GHP. Discussed groundwater heat pump systems for large buildings. Based on experience, three items are critical to successful applications: 1) drill and test wells prior to system design, 2) perform complete water chemistry analysis on well fluids, and 3 ) isolate groundwater from the building mechanical system with heat exchangers (5-28-93).

GHP. Discussed geothermal heat pump technologies, groundwater and ground-coupled systems, and costs. Provided a contact in Kentucky and sent literature and listing of manufacturers (5-28-93).

Greenhouses. Discussed cost of greenhouse heating equipment using $96^{\circ} \mathrm{F}$ water to heat a $20,000 \mathrm{ft}^{2}$ greenhouse with double plastic roof and single fiberglass sides. For four different inside temperatures ranging from 50 to $65^{\circ} \mathrm{F}$, the cost ranged from $\$ 1.80$ to $\$ 3.70 / \mathrm{ft}^{2}$. suggested a hybrid system be considered in which geothermal provides the base load and a fossil fuel such as propane provides peak load energy. The advantages are: 1) it can reduce the capital costs of the heating system, and 2) the fossil fuel peaking system can provide some emergency backups in the event of failure of the geothermal system $(6-1-93)$. 
2.41 Chuck O'Donnell

U.S. BLM

1800 Marguess street

Las Cruces, NM 88005

2.43 Rob Colman

Frontier Aquadine

576 "B" street

Santa Rosa, CA 95401

2.42 Stephen M. Carnody

P.O. BoX 724

Augusta, ME 04330

2.44 Darrell Jackson

Yreka High School

Yreka, CA

2.45 Elon Yurwit

Dreamlight Images Inc.

932 N. LaBrea Avenue Hollywood, CA 90038

2.46 Roger Peake

CEC, MS -43

1516 Ninth street

Sacramento, CA 95814
Equipment. Reviewed draft specifications for the metering system of Burgett Floral, Lightning Dock KGRA, New Mexico. Comments included calculations methods, equipment requirements for flow meters, RTD temperature probes, calibration and maintenance, and how to monitor wells using a downhole heat exchanger (6-1-93).

Industrial. Discussed low-temperature desalination equipment and proposed project in Colorado. Explained how the GHC could help through the technical assistance program (6-1-93).

General. Requested information on renewable energy. Sent information and letter on geothermal direct uses, especially geothermal heat pumps $(6-1-93)$.

space Heating. Reviewed well logs for a geothermal heat pump system for the high school. Phoned well driller--checked with $C A$ water resources, and Mines and Geology. New well is not producing as expected; but, no good geology available in the town to base recommendations on. Pump test report $350 \mathrm{gpm}$ at $40-45 \mathrm{ft}$ pumping level for $45 \mathrm{~min}$; then dropped to $150 \mathrm{ft}$ in $15 \mathrm{~min}$. and broke suction after $20 \mathrm{~min}$. Produced only $120 \mathrm{gpm}$ with 150 ft pump level, water "cloudy." Initially assumed cave in since cased only 48 ft; but, Darrell checked depth which was still at the original $200 \mathrm{ft}$. Must be boundary or taking water from limited gravels (6-2-93).

Resort. Requested information on hot springs to purchase. Had questions about Maple Grove Springs, Idaho; Magic Springs, Nevada, and Jackson and Elkhorn Springs, Montana. Provided chemistry and other information over the phone (6-2-93).

Equipment. Discussed downhole heat exchangers--explained how they work, and where they will and will not work. The reasons they will probably not work at Alturas are: 1) deep wells--resistance to flow gets high and heat conduction through the casing on convection promoter short circuits the convection cell, 2) no convection promotion perforations, 3) high permeability and relatively high hydraulic gradient required, and 4) DHE 


\subsection{Dean Day \\ City Engineer \\ Ely, NV}

2.48 Erik Berall

$1025 \mathrm{~S}$. Cloverdale Avenue

Los Angeles, CA 90019

2.49 Scott Baker

Spice Island Farms

7318 Batavia Road

Dixon, CA 95620

2.50 Doug Bell

John Curollo

Engineers

$450 \mathrm{~N}$. Wiget Lane

Walnut Creek, CA 94598

2.51 Ray Grozell

Modoc Pump Co.

Cedarville, $C A$

2.52 Ruben Castillo

WNC, D-C-1, 126899

P.O. Box 1260

Winnfield, LA

71483-1260 would work with a well bleed; however, more heat could be obtained using a plate heat exchanger with the same bleed flow $(6-3-93)$.

Pool. Investigating potential of using Cackawana Hot Springs for swimming pool $-40 \times 90 \mathrm{ft}$ wood structure cover. Checked data--temperature $75-90^{\circ} \mathrm{F}$ at $240 \mathrm{gpm}$. Checked with Nevada Health Department--probably need to disinfect (chlorinate) pools and spas. Flow throughs can be used if drained and cleaned after each use. Spring temperature marginal for pool--suggested drill well and for improve springs. Checked with Nevada state Engineer Office--no wells within 2 miles. Rich Skivers, environmental health specialist in Ely, can help/advise on health requirements for pool. Sent all information that could be found, mostly from NBMG and Larry Garside $(6-3-93)$.

General. Requested information on geothermal direct uses. Provided publications listing, back issues of the GHC Bulletin and described the technical assistance program (6-4-93).

Industrial. Discussed proposed drying plant development which included: well depth, flow and temperature, type and manufacturer of drying system, annual output and source of raw product, and finished product (6-7-93).

Resource. Requested resource information on Lightning Dock KGRA. Provided 1983 geology and geochemistry study. Discussed status of power company and direct heat $(6-10-93)$.

Equipment. New well located approximately 5 miles north of Cedarville--135 $\mathrm{F}$. Requested information on pipe for radiant heating. Provided information on temperature/pressure limits on the phone (6-993).

General. Requested information about GHC and back issues of the Bulletin. Discussed Center programs and sent publications request form (6-14-93). 
2.53 Dimitri stamatiou 3838 Rainbow Blvd. Kansas City, KS 66103

2.54 City of Susanville Susanville, CA

2.55 Don Yamada

U.S. General

Accounting office

San Francisco, CA

2.56 Rob Bloomquist

Bentley, NV

2.57 City of Susanville Susanville, CA

2.58 Frank Hall

11210 Wilson Road Utica, OH 43080

2.59 Lisa Powell

210 N. 6th Street

Grand Forks, ND 58203

2.60 Elon Yurwit

932 N. LaBrea Avenue Hollywood, CA 90038
Aquaculture. Requested cost analysis for aquaculture project in Greece. Provided names of two U.S. consultants who have had experience with aquaculture. Provided comments on U.S. example and on pond heat loss (6-16-93).

Equipment. Profiled depth/temperature log of Richardson Well No. 1. Also, gathered information on and inspected failed pump out of Susan No. 1. Pump locked up after power failure--no lateral movement. Sending pump back to Hays Pump, Anderson, CA for inspection $(6-17 \& 18,93)$.

Industrial. Discussed exclusion of TEOR from the direct-use database. In most cases of the Powder River Basins of MT, ND and WY, water is injected at a lower temperature, then the in-situ reservoir; therefore, there is no thermal enhanced oil recovery. Provided status and updated table of U.S. direct use (6-23-93).

Equipment. Discussed for pump problems analysis using vibration analysis equipment. Can tell when problem is about to occur, but probably not reason (6-24-93) .

Equipment. Traveled to Anderson, CA--Hays Pump Co. to witness tear down of Susan No. 1 pump. No apparent reason for lockup? (6-28\& 29-93).

GHP. Owns a $4000 \mathrm{ft}^{2}$ home in a rural setting and wants to install a geothermal heat pump. Discussed groundwater heat pumps using an existing well vs a groundcoupled system. Provided estimated costs and referred to Buckeye Power. Also, sent information on both groundwater and ground-coupled systems (6-29-93).

General. Working on a research project on renewable energies and specifically geothermal direct use. Provided general information on direct use and some specific examples (6-29-93).

Resort. Called to talk about Symes Hotel Hot springs, MT. Thinking about purchasing the resort. Provided water chemistry and general geology. Discussed greenhouse heating methods and temperatures $(6-30-93)$. 


\section{$3.0 \quad R \& D$ Activities.}

3.1 Evaluation of Lineshaft Vertical Turbine Pump Problems

The following is an interim report on specific pump failures for: 1) Susanville District Heating System Well - Susanville No. 1, 2) Modoc High School, Alturas, CA Well No. AL-1, and 3) College of Southern Idaho and Ross Colahan, Paisley, OR.

This project relies on real pumps in real applications rather than laboratory type testing. In this regard, it is similar to holes of opportunity in geological studies. One problem is to find pumps of opportunity. Requests will be sent to pump manufacturers, suppliers and users to obtain more data.

susanville District Heating system Well - susan \#1

Pump

Ingersol Rand - $10 \mathrm{NK}$ bowls - H impeller 7.28 inch diameter - 8 stage - $11 / 2$ inch sst shaft. Bowls and impellers cast iron. $800 \mathrm{gpm}$ a $243 \mathrm{ft}$ head. Pump bearings EPDM rubber.

Pump was set at $140 \mathrm{ft}$. Static water level $15 \mathrm{ft}$ and pumping level at $800 \mathrm{gpm}$ estimated at $100 \mathrm{ft}$. Pumping temperature $174^{\circ} \mathrm{F}$. District heating system has never realized full build out, so pumping rate probably never exceeded $350-400 \mathrm{gpm}$. Variable frequency drive controls pumping rate to match requirements.

Column is enclosed lineshaft oil lubricated with $21 / 2$ inch tube. $11 / 2$ inch shaft with bronze bearings on $5 \mathrm{ft}$ centers.

Symptoms

According to pump installer, this pump was "tight" at installation. Shaft was difficult to turn by hand and lateral difficult to adjust. Lateral was adjusted to top, then backed

off, according to manufacturer's specifications. Motor current was initially high, but reduced to normal after several hours run in.

This pump operated satisfactorily for approximately 18 months (exact dates of installation and removal are being confirmed). After a power failure in early June 1993, the pump could not be restarted. Drive motor stalled and lateral could not be adjusted either up or down and the drive shaft could not be turned with a pipe wrench.

Note that the pump had previously restarted after several power failures during its installed time.

A new (rebuilt) pump was installed using the same column, shaft and bearings. The column bearings reportedly showed very little wear. 
On June 18, 1993, the pump was briefly inspected in the TriCounty Pump yard near susanville. An antectodal history (above) was obtained from the owner Larry cravey. The pump was subsequently shipped to Hays Pumps in Anderson, $C A$, for disassembly and inspection.

On June 29, 1993, the pump was disassembled at Hays Pumps with a Geo-Heat Center staff member witnessing. Prior to disassembly, the pump shaft could not be turned and there was no lateral movement.

\section{Inspection Results}

When the center staff member arrived, the pump was on a pump stand with the tail (inlet) and head (outlet) sections removed and not apparent. Presumably, these had been reused in the installation of the replacement pump. The tail bearing area looked to be in new condition--scratching with a fingernail could not detect any wear in the bearing area. At the headshaft bearing location, there was slight detectable wear around approximately 120 degrees of the pump shaft. This later was dial indicated and found to be 0.004 inch.

Disassembly proceeded about normal. Exceptions were--initially the top impeller could not be driven off the collet. It was decided to try disassembly from the bottom up; but, the collet could not be driven up inside the impeller. Heat was used on the bottom impeller with no better results after a number of hits with the slider. At that point, it was noted that the top collet had loosened in the top impeller and was disassembled. Disassembly proceeded normally from top down. Each impeller and bowl was visually inspected for wear as disassembled. The third from bottom impeller was noted to have a crack in its hub and extending to the outer end of the vane, but did not extend to the skirt. There was no rotation or lateral movement until the second from bottom impeller was loosened from its collet.

Bowels and matching skirts were measured after disassembly. All clearances were $0.010 \pm 0.001$ - including \#3 with the cracked hub.

Shaft run out was dial indicated at $0.002-0.003$ except at discharge bearing noted above. Bearing wear areas were shiny, but could not be detected by fingernail. Rubber bearings appeared to be in the like new condition. Machining marks could be seen on both bowls and impellers indicating there had been no lateral wear. Bowls and impellers were shiny for about 5/16 inch indicating where impellers had been running; but, this was not detectable by fingernail or micrometer.

During disassembly, a black flaky material was noted in the bowls--probably iron sulfide--it broke down to a very fine powder when rubbed between fingers. Each bowl had about the amount that could be picked up by scraping with two fingers--less than $1 / 8$ teaspoon--some in the bowl itself and some in the bowl/skirt running area. 


\section{Conclusions}

None.

All normal and abnormal wearing surfaces were in new or near new condition. There were no indications of seizure. Hays pump engineers felt that the black flaky material may have settled into the 0.010 clearance between the impeller skirts and bowls, and bound the pump, similar to sand binding a well pump screen to remove it. Particles found in the bowl/skirt area were smaller than those in the bowl itself--perhaps crushed while driving impellers off the collet?

The reason for this pump seizure will probably never be known for sure.

No serial number could be found on the pump. Records of purchase and installation being checked.

Modoc High school - Alturas, CA - Well \#AI 1

Pump

Worthington, $\mathrm{BL} 12,11$ stage, 9 impellers 5.81 in. trim, 2 impellers 5.13 in. trim, a $1760 \mathrm{rpm}, 80 \mathrm{gpm}$ with $347 \mathrm{TDH}$. Enclosed lineshaft pressure oil lubricated. pump setting $320 \mathrm{ft}$. Serial number C51591.

Total lateral $11 / 16$ in. after machining extra $1 / 4$ inch.

Bearing material specified was Bronze ASTM B271 Alloy 932 - Cu 83\%, Sn 7\%, $\mathrm{Pb} 7 \%, \mathrm{Zn} 3 \%$ centrifugly cast. Bowls and impellers cast iron.

Worthington drawing, material and pattern information on file.

Pump Installed by Modoc Pump Co., Cedarville, CA. Interview indicated no installation problems--no hang up, well straight, pump and column could be easily rotated by hand when at setting depth. Normal start up--no excessive current draw on motor. Novibrations noted; although, it is unclear what the rpm ranges were, Pump is run on variable frequency drive and has bypass back to well to provide minimum recommended flow through pump when entering system is calling for minimum heat.

\section{Symptoms}

Pump was installed in March 1990 and ran satisfactorily through remainder of school year. Pump was run intermittently to provide hot water for showers during summer. The following school year, the pump seemed ok; but, by January of 1992, flow at given rpm was notably reduced and in order to maintain heat for school, rpm was increased. By May, flow was significantly reduced and pump was "noisy." Pump was pulled in June 1992. Approximately 20 months of satisfactory service had been achieved. 


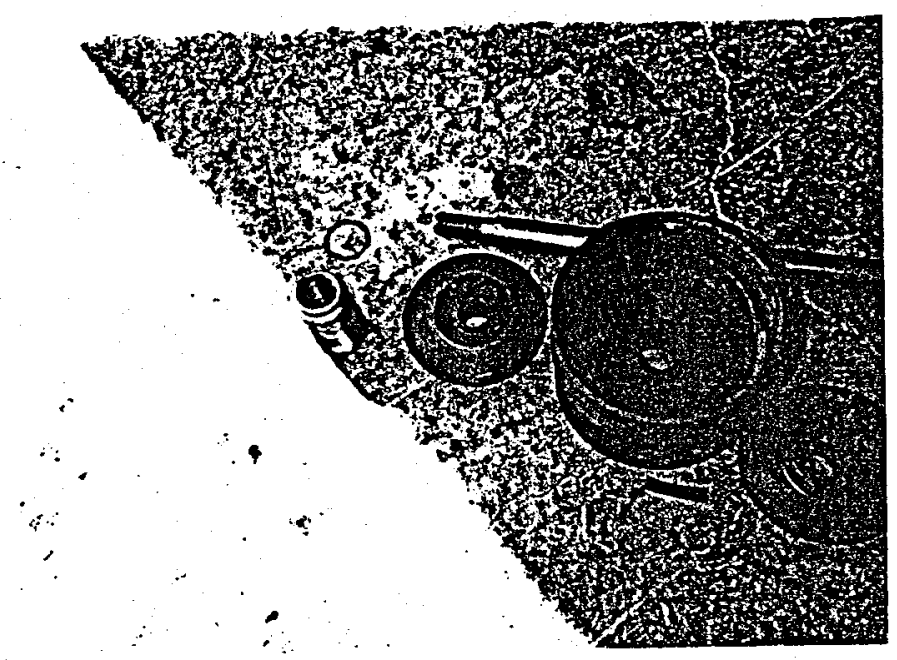

'Left to right bottom: oil tube brg., top impeller, top bowl, and 2nd impeller.

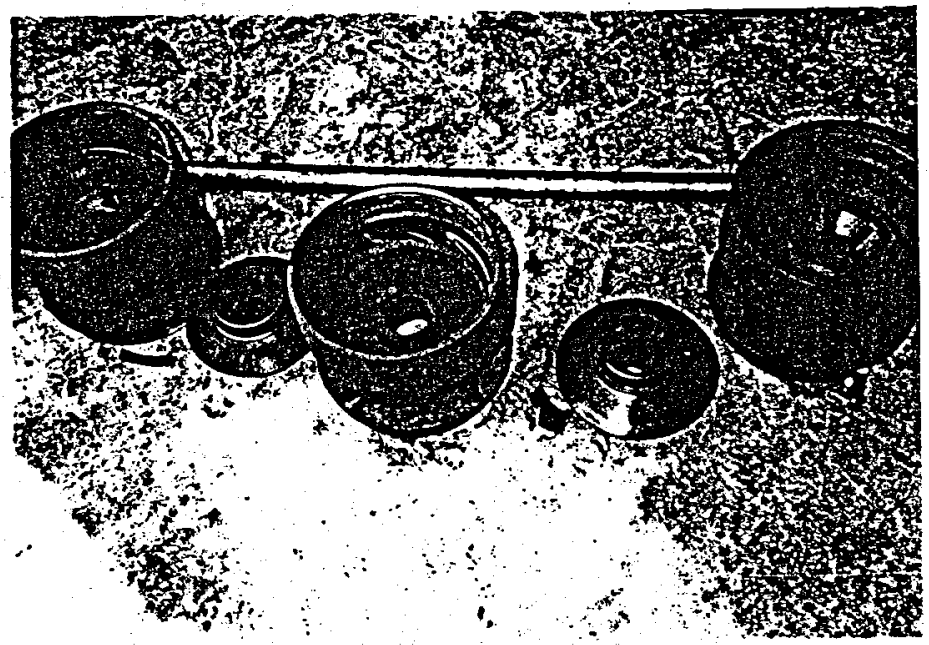

Top bowl, 2nd impeller, 2nd bowl, 3rd impeller, 3 rd bowl, and mis. bearing remains.

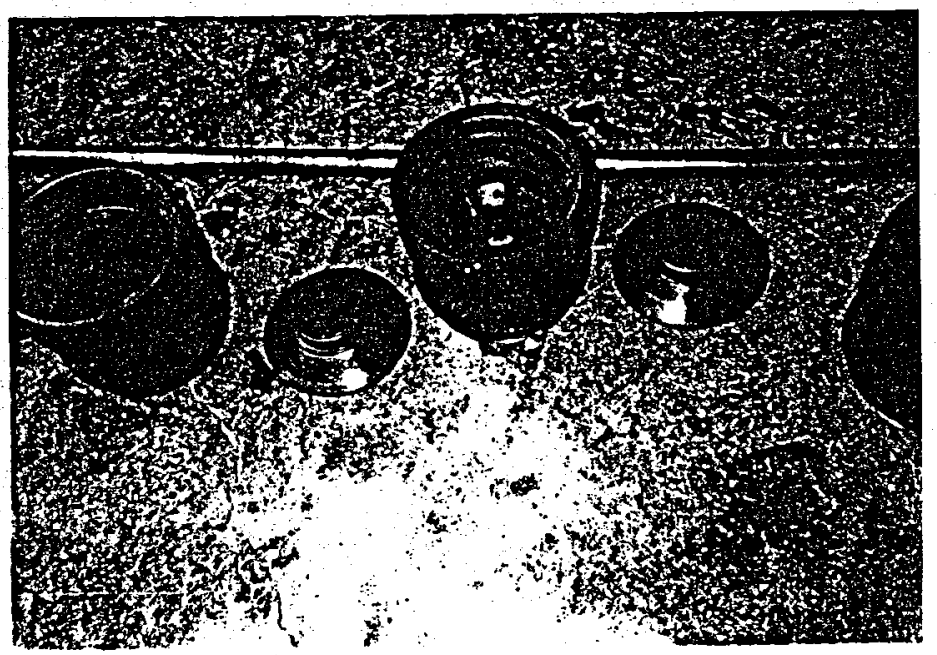

3 rd bowl, 4 th impeller, 4 th bowl, and 5th impeller. 


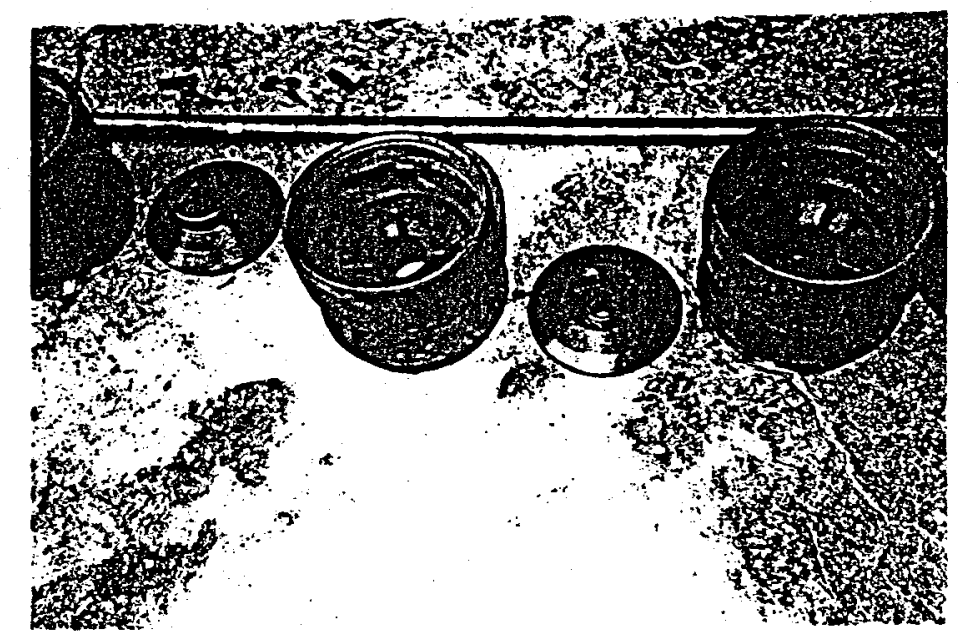

4 th impeller, 4th bowl, 5th impeller, and 5th bowl.

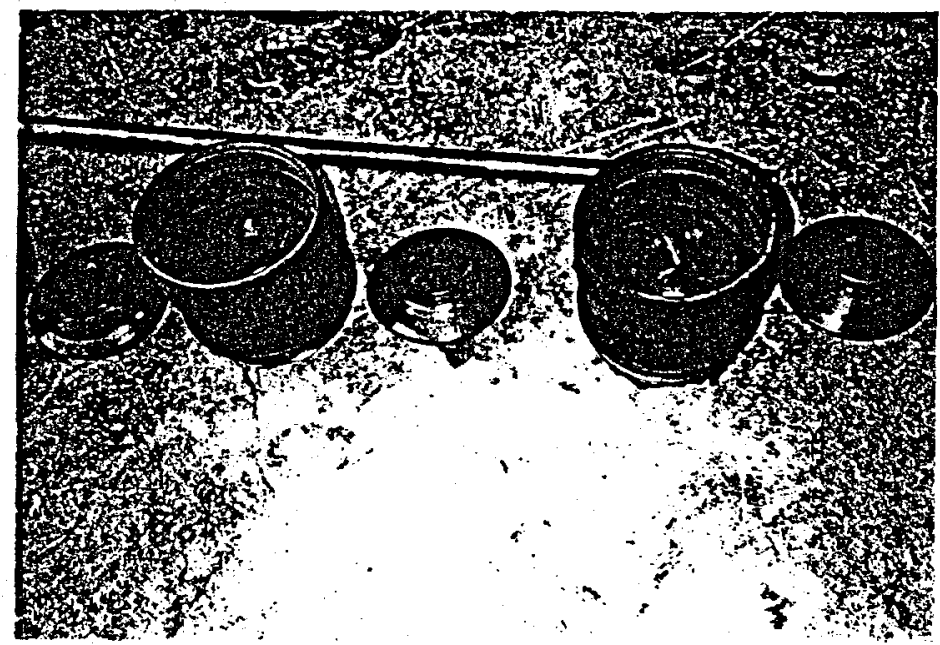

5 th impeller, 5th bowl, 6th impeller, and 6 th bowl.

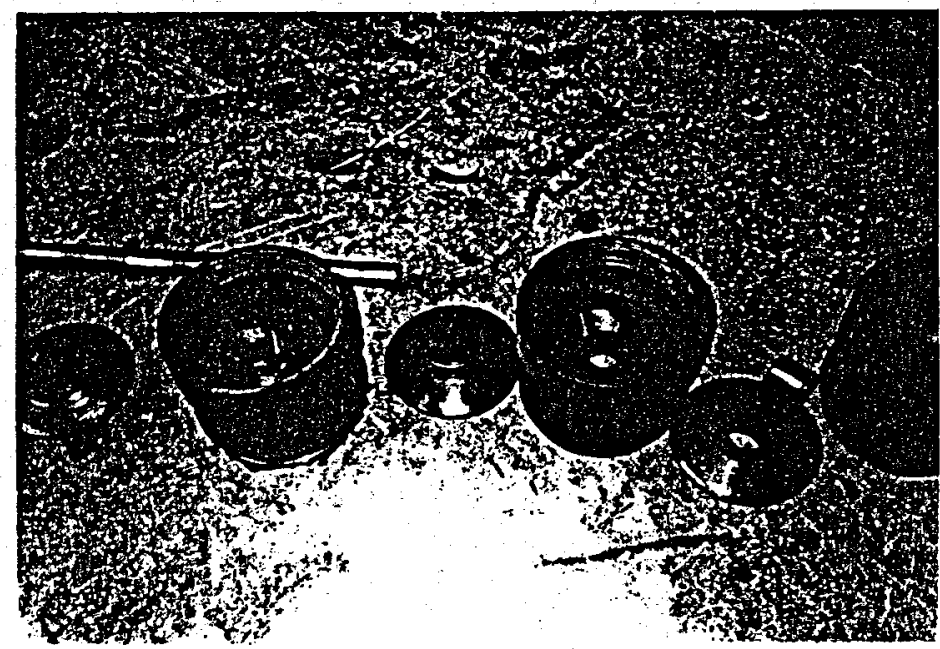

9 th, 10th and 11th impellers and bowls. 


\section{Inspection}

A Geo-Heat center staff member was on-site for pump tear down. Results of the inspection are shown in the photos.

The lower bearing in the oil tube was badly worn--hour glass shaped. There were only bits and pieces of bowl bearings except for the tail bearing which was worn but still intact. starting at the top, the first impeller skirt was worn completely away; 2nd, 3 rd and 4 th impeller skirts were worn but still attached; 5 th and 6 th skirts were completely gone; 7 th worn but attached; 8 th completely gone; and 9th, 10th and 11th skirts were there. The 11th or bottom impeller and bowl showed the least wear. Lateral had been correct as evidenced by no wear on top of impellers and machining marks visible on bottoms. An identification number was readable on the bottom impeller.

Impeller and bowl vanes appeared in as cast condition indicating no sand pumping cavitation or recirculation problems.

The stainless steel pump shaft was in surprisingly good condition. There was visible wear at the bearing areas; but, it was even indicating the shaft was straight. Apparently, the impellers were acting as bearings during the later stages of pump 1 ife.

\section{Conclusions}

Nothing specific. The alternating nature of wear suggests a critical speed problem. It's impossible to determine the initial cause. It is possible the rotating parts were initially out of balance; but, this is usually detected during pump testing at the manufacturer. However, if the manufacturer was not aware the pump would be operated on a variable frequency drive, it may not have been tested through the entire operating speed ranges. There is no record to confirm this one way or the other.

One of the bearings may have prematurely worn allowing vibration to start--which would be self perpetuating.

During a discussion of this pump with an ex-pump designer/trouble shooter for a major pump manufacturer, now a private pump consultant, it was noted that top bearing problems have been caused by insufficient oil tube tension either through lack of tension during initial installation or due to alternating on/off operation and the resulting thermal expansion.

The bearing material is higher in tin content and lower in $z$ inc which should make it less susceptible to dezincification noted in some geothermal components. 
College of Southern Idaho

Pump

American Turbine, Model $11 \mathrm{H} 110,3$ stage 189 TDH a $1760 \mathrm{rpm}$, pump setting $220 \mathrm{ft}, 8$ inch column, water lubricated, column bearings on $10 \mathrm{ft}$ centers.

Pump bowls, impellers and bearings specified as zincless bronze due to poor experience with zinc alloy bronzes in valves and fittings. $13 / 16$ stainless steel bowl shaft.

Pump variable frequency controlled specified $1200 \mathrm{gpm}$ a $189 \mathrm{ft}$ TDH a $1760 \mathrm{rpm}$. Well is artesian, but won't handle high loads on artesian. Pump tested at 50\% speed--441 gpm with $20 \mathrm{ft}$ pumping level. At 100\% speed $1174 \mathrm{gpm}, 11 \mathrm{psi}$ at surface, $121 \mathrm{ft}$ pumping level.

Maximum temperature $98^{\circ} \mathrm{F}$. Water analysis in file.

Pump installed late September 1992, failed December 1993 with about 200 hours run time.

\section{Symptoms}

Pump vibrated during initial start up at $25-40 \%$ of full speed. Variable frequency control set to run through that speed range quickly and to block out continued operation at those speeds. vibration not noticeable at $50 \%$ and above.

Pump slowly pumped less and less, vibration got worse and worse. Complete failure December 1993.

Inspection

Pump was not inspected by Geo-Heat.

Initial inspection at Funk Irrigation showed top bearings worn most tapering off to tail bearing. Bowls and impellers worn out, pump shaft broken. Column bearings ok.

Pump was shipped back to American Turbine for failure analysis.

Teleconference July 1, 1993, with Dan Buetner, CSI maintenance supervisor, reported pump had been inspected by American Turbine and an independent pump consultant. Both concluded problem was due to improper installation--an alignment problem. It has not been confirmed whether the pump was or was not test run at manufacturer.

Conclusions

This pump should never have been allowed to stay in hole after vibration was noted at initial start up. 
Purchase pump from reputable pump dealer and be sure he understands proposed operating conditions.

3.2 Geothermal District Heating Marketing strategy

The Geo-Heat Center has been assisting the city of Klamath Falls in marketing the city's geothermal district heating system to commercial building owners in the downtown cove area. The marketing approach which eliminates heat exchangers, energy meters (expensive to install) and offers heat on a flat rate basis has been very successful.

The enclosed report describes the market strategy developed design to address the following major issues:

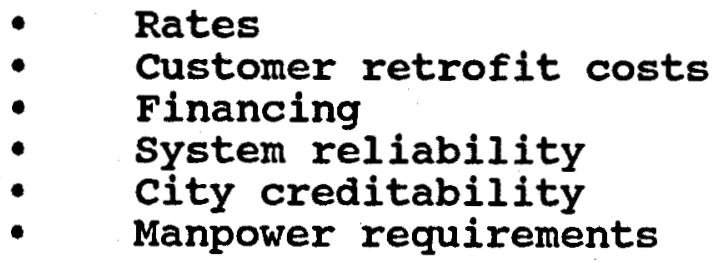

Other cities promoting geothermal district heating systems could possibly benefit from the approach taken by Klamath Falls.

3.3 Greenhouse Peaking Analysis

As a result of a technical assistance request from colorado, an addition has been made to the previously developed GHS (Greenhouse Heating systems) spreadsheet. The addition allows for the calculation of fuel use by a non-geothermal (propane, electric, fuel oil, etc.) peak heating system.

In the Colorado project, an individual was interested in developing a greenhouse using a very low temperature resource (98 ${ }^{\circ} \mathrm{F}$ ) in a very cold climate (Alamosa). In this particular case, it appeared that designing the geothermal system for the base load (approximately $60 \%$ of peak) and providing peak heating with a conventional fuel would be an economical design strategy. To optimize the design, it was necessary to calculate fuel consumption for a variety of cases.

Using input information including greenhouse heat loss, design temperatures, peaking fuel type, combustion efficiency, and percentage of design loss served by the geothermal and peak systems, the spreadsheet calculates the peaking fuel required on an annual

basis. The fuel consumption is separated into day and night categories to allow for night setback if used. Calculations employ bin types weather data. 
GREENHOUSE PEAKING SFREADSHEET

$5-20-93$

Night Temp

Day Temp

Efficiency

UA

Sunshine

$\begin{array}{rl}55 & F \\ 70 & F \\ 300 & \% \\ 3240 & \text { btu/tir F } \\ 0 & \%\end{array}$

\% Design

Out Des $T$

Fuel Energ

Geo Cap

Fuel Use

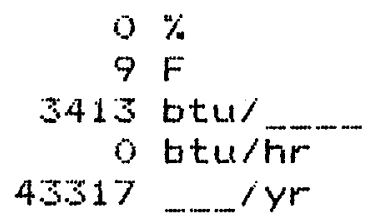

$0 \%$

43317 iyr

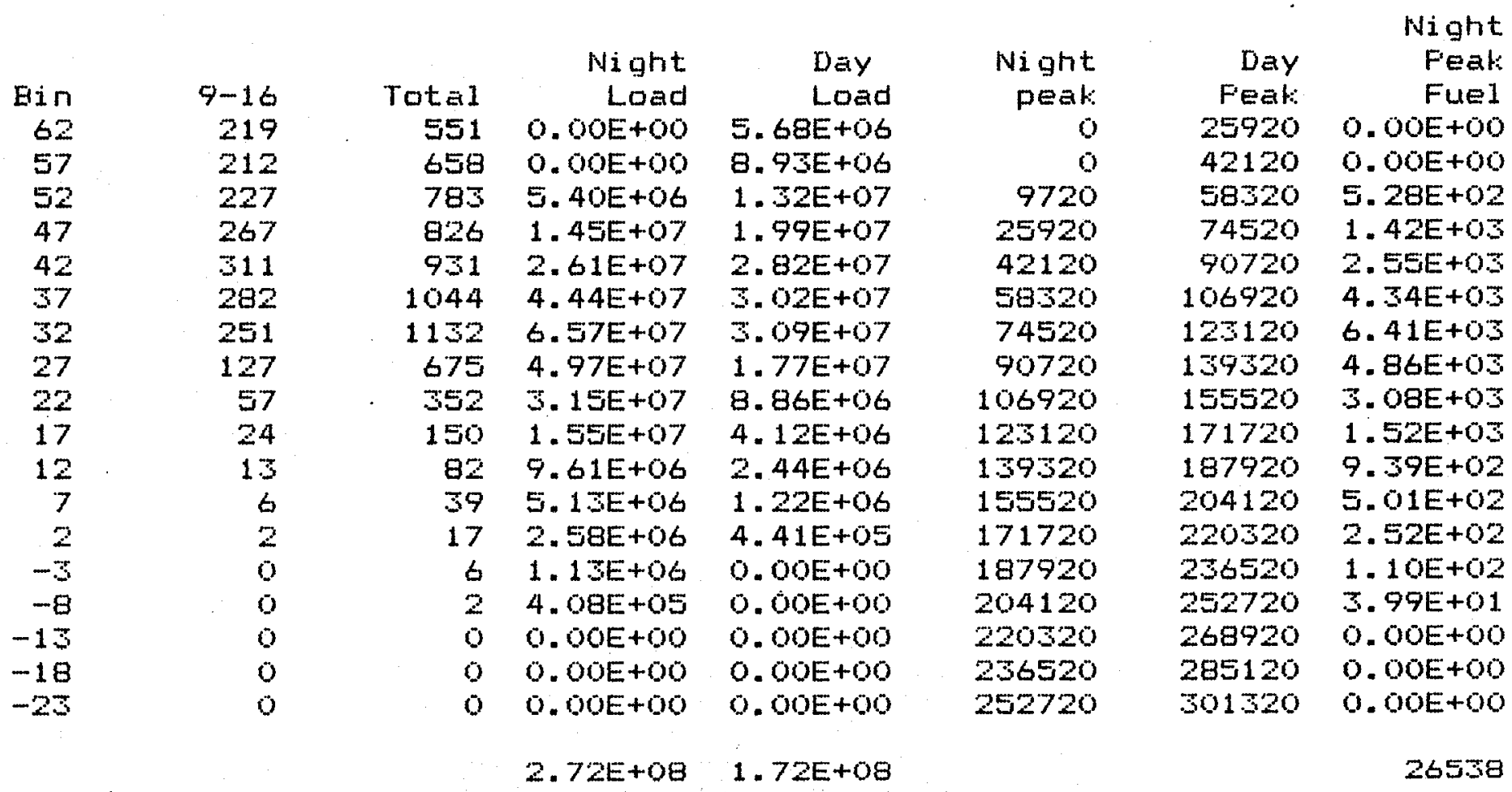

Notes:

1. assumes that the geothermal system can meet all loads during the 9 to 16 hour period.

2. All calculations made at the bin midpoint temperature.

3. Assumes that the geothermal system continues to run along with the backup system at low temperatures. 
It is possible that during installation the portion of shaft sticking out above pump upper bearing was bent--by improper handling after uncrating or by initial lifting from ground to well by attaching to shaft head.

Ross Colahan, Paisley, OR

Pump

Worthington 8 in. OD 5 stage semi-open impellers. Pump was used and reportedly newly rebuilt when purchased--as is, where is. No data on model or serial numbers. Pump is used to pump irrigation water to pond for cooling. on/off operation. Temperature $234^{\circ} \mathrm{F}$.

\section{Symptoms}

Reduced flow and noisy. No record of run hours or number of cycles.

\section{Inspection}

Second impeller collet had slipped allowing impeller to ride on bowl--impeller and bowl badly worn. other impellers and bowls worn showing lack of lateral length or poor lateral adjustment. Shaft broken at slipped collet.

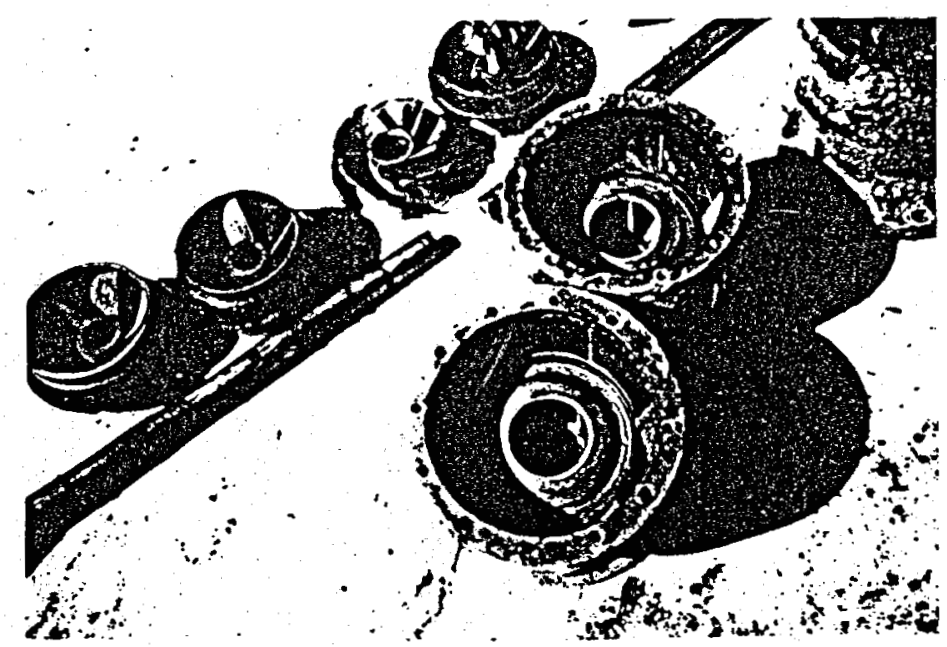

Ross Colahan pump $230 \mathrm{ft}-11 / 2$ yrs operation, shaft broken at impeller locating snap ring.

\section{Conclusions}

Use keyed and screwed collets when pumping water this hot.

Assure proper lateral allowance. Ross is $85+$ years old and others often start and step pump. It seems probable pump was started, warmed up and lateral adjusted each time cooling pond was filled (about 7 times per summer). 

Day
Feat: Geothermal
Fuel Day
$5.54 E+02$ 4. $33 E+01$
B. $72 E+02$ 4.19E+01
1. $29 E+03$ 4. $49 E+01$
1. $94 E+035.28 E+01$
2. $76 E+03$ 6.15E+01
2. 94E+03 5.57E+01
$3.02 E+03$ 4. $96 E+01$
1.73E+0S 2.51E+01
8. GSE+02 1. 13E+01
$4.03 E+02$ 4.74E+00
2. $39 E+02$ 2.57E+00
1. 20E+02 1. 19E+00
4. 30E+01 3.95E-01
$0.00 E+00 \cdot 0.00 E+00$
$0.00 E+00 \quad 0.00 E+00$
$0.00 E+00 \quad 0.00 E+00$
$0.00 E+00 \quad 0.00 E+00$
$0.00 E+00 \quad 0.00 E+00$

$16779 \quad 3.95 E+02$ 
4.0 Technology Transfer.

GHC staff provided the following outreach and information dissemination services during the third quarter:

4.1 Technical Papers, Presentations and Tours.

1. Technical Paper. Oregon Business Magazine--article on the city of klamath Falls geothermal district heating system including savings, expansion and marketing strategy (5-693).

2. Tour and Discussion. Don Yamada, GAO, San Francisco-reviewed geothermal district heating, geothermal heat pumps and resource assessment program. Toured OIT and city district heating, residential system and Iiskey Farms greenhouses and aquaculture facility (5-20-93) .

3. Presentation. ASHRAE meeting, "Environmental Considerations for Geothermal Energy As A Source For District Heating" by Kevin Rafferty.

Abstract:

Geothermal energy currently provides a stable and environmentally attractive heat source for approximately 20 district heating (DH) systems in the United states. The use of this resource eliminates $100 \%$ of the conventional fuel consumption (and hence, the emissions) of the loads served by these systems. As a result, geothermal DH systems can rightfully claim the title of the most fuel efficient DH systems in operation today.

Costs for producing heat from a geothermal resource. (including capitalization of the production facility and cost for pumping) amount to an average of $\$ 1.00$ per milition Btu.

The major environmental challenge for geothermal system is proper management of the producing aquifer. Many systems are moving toward injection of the geothermal fluids to assure long term production.

4. Presentation. ASHRAE Technical Committee 6.8 on Geothermal Energy Utilization--handbook and geothermal heat pump terminology $(6-29-93)$.

5. Technical Paper. Reviewed and commented on "Geothermal Heat Pump Systems" by Phillip M. Wright and stefanie Colvin (621-93).

6. Technical Paper. Prepared technology transfer examples for DOE publication. Examples included: Yakima Detention Facility, San Bernardino Geothermal District Heating System, Klamath Falls Geothermal District Heating System, Modoc High School, and Newcastle Geothermal system (Howard Ross, UURI). 
4.2 GHC Quarterly Bulletin. Bulletin Vol. 14, No. 4 featured thermal springs in the U.S. and was mailed to $1703 \mathrm{U} . \mathrm{S}$. subscribers and 298 foreign.

Plans for Bulletin Vol. 15, No. 1 include progress and development of Alturas geothermal system, Klamath Falls marketing strategy, resource assessment program, ancient uses of geothermal energy and the pipeline.

4.3 Geothermal Library. Thirty one volumes were added to the library during the third quarter. Work continued with the computerized library system with 663 entries of the library in the program.

4.4 Information Dissemination. The GHC provided the following with publications:

Name

$4 / 5 / 93$

Robin McGuire

Alliance, $\mathrm{OH} 44601$

$4 / 13 / 93$

Antonio Nevcs Trota

S. Miguel - Acores, Portugal

$4 / 19 / 93$

Benny Teale

Dalles, OR 97338

David Wheeler

Glenshaw, PA 15116

$4 / 20 / 93$

David Collar

Caldwell, ID 83605

$4 / 21 / 93$

Manville B. Rose

Huntsburg, OH 44046

$4 / 22 / 93$

Marita Kunkel

Klamath Falls, OR 97601

3

No.

Publications

3

GHP

6

GDH

3

GHP

3

GHP

7

Greenhouses

$4 / 23 / 93$

David Mead

Ridgecrest, CA 93555
GHP

GHP

Other 
$4 / 27 / 93$

Bob Carr

GHP

Holt's Summit, MO 65043

$4 / 29 / 93$

Bill Richardson

6

other

Beaverton, OR 97005-4421

$4 / 30 / 93$

Jeff Sims

3

GHP

Sisters, OR 97759

Richard I. Williams

3

other

Pleasantville, NJ 082324051

$\underline{5 / 4 / 93}$

Gladys J. Hooper

Washington, D.C. 20585

other

$5 / 10 / 93$

Rebecca Christie

31

Greenhouses

Olympia, WA 98504-7007

Aqua

other

$5 / 11 / 93$

Steve Rubin

9

GHP

Golden, Co 80401

Greenhouses

GDH

$6 / 15 / 93$

Joe La Fleur

3

other

Springfield, OR 97448

$6 / 16 / 93$

Germelino F. Abito

5

GHP

Diliman, Quezon City,

Philippines

$6 / 17 / 93$

Bill Marci

other

Fort Collins, $c 0$

$6 / 29 / 93$

Frank Hall

GHP

Utica, OH 43080 
Meeting Announcement

USGS Forum on Mineral Resources

U.S. Geological Survey, 9th V.E. Mckelvey Forum on Mineral Resources, February 22-25, 1994, Tucson Convention Center, Tucson, Arizona. Contact: Warren C. Day, U.S. Geological Survey, Box 25046, MS 905, Denver Federal Center, Denver, Colorado 80025, (303) 236-5568, FAX (303) 236-5603.

The forum will feature:

- Geology and mineral deposit studies of the southwestern U.S. and Latin America

Mineral resource assessments and land use planning

Minerals resource-related environmental studies

Field trips in southeastern Arizona

General

Renewable Energy Tax Credits Not Working As Congress Intended, Geothermal Industry Tells House Panel

Thomas C. Hinrichs, President of the Geothermal Resources Association, told a House Ways and Means Subcommittee that the 10 percent tax credit for investment in solar and geothermal development--recently made permanent by Congress--isn't sparking investment because the credit is presently not allowed to be used against the Alternative Minimum Tax, or AMT.

Because of relatively higher initial costs, the AMT "is almost always triggered in the case of companies involved in geothermal development, and therefore, the geothermal tax credit is not available to do the job congress intended it to do," Hinrichs told the panel.

"We strongly urge the subcommittee and the Congress to support the full utilization of the energy tax credits against the AMT," he said.

Hinrichs, a Vice President of Magma Power Company of San Diego, praised the tax credit as "the single most effective federal program to promote renewable energy, stimulate investments and enable the technology to develop and improve."

"If the inability to apply the tax credit against the AMT was corrected by legislation, it would result in lower renewable energy prices being put forward in the bidding process" and "will enable renewable projects to compete with conventional fossil fuels in the bidding for new utility projects, " Hinrichs testified. 
"Such successful bidding will result in the twin national benefits of energy independence and environmental enhancement," he added.

Hinrichs noted that "ironically, twice in the last three years the oil and gas industries have received relief from the AMT in tax legislation. Coupled with other tax breaks enjoyed by the oil and gas industries, renewables remain some distance from reaching the proverbial 'level playing field'."

Hinrichs said the legislation introduced by U.S. Rep. Jim MCDermott (D-Washington) (H.R. 2026) to allow the tax credits to apply against up to 25 percent of the AMT "is a fine start." But he stressed that "full utilization is the catalyst needed to spur renewable development."

He underscored the tremendous potential geothermal energy has for helping power America with clean, renewable and domestic sources of energy.

"Geothermal energy is environmentally benign, a fact which is of particular importance in an era of global warming stemming from excessive carbon emissions and air pollution caused by other harmful pollutants being emitted into the atmosphere," Hinrichs said.

The Geothermal Resources Association is comprised of 15 geothermal energy companies which operate geothermal energy facilities producing a total of approximately 2,800 megawatts of clean power. A 100-megawatt power plant can support the energy needs of a community of 100,000, he noted. (Source: Geothermal Resources Association)

oregon

Geothermal Drilling ok'd Near Fields

A government appeals panel has authorized Anadarko Petroleum corp. to drill more geothermal test wells this fall near an eastern Oregon high desert lake that is the only home of a tiny endangered fish.

Barring further appeals, Anadarko hopes to drill two new exploratory welis and deepen an existing one after a summer moratorium expires at the end of August, Patrick A. Smith, project landman for Anadarko, said Friday from Houston.

Smith said the site is the most promising for commercial development of geothermal energy in the northwest. A coalition of environmental groups had demanded the U.S. Bureau of Land Management do a complete environmental impact statement examining the possibility of developing a commercial power plant at the site, located outside the town of Fields in Harney county. (Source: Herald \& News) 
Newberry Geothermal Pilot Project

CE Exploration Company (CEE), the project's proponent, is the Oregon-based subsidiary of California Energy Company, which is one of the country's largest independent producers of geothermal energy and now has six operating geothermal facilities in the western United States. Eugene Water \& Electric Board (EWEB), coproponent of the proposal, is Oregon's largest municipally-owned electric utility. In its 80 years of operation, it has developed a variety of small-scale, renewable power resources.

The proposal from CEE and EWEB is to drill a series of exploration wells to depths of 6,000 to $10,000 \mathrm{ft}$ in order to test the availability of geothermal resources. They would need to find and be able to produce water at temperatures in excess of 400 degrees Fahrenheit in order to proceed with development. Assuming the geothermal resource is adequate, and also assuming that this pilot project is approved and successfully implemented, there is the potential for further expansion of $100 \mathrm{MW}$. However, further environmental analysis with additional public participation would be required before a decision could be made to approve any expansion or additional development.

The proposed power plant would require up to 10 production wells and three injection wells located within three miles of the plant site. Two or more of these production wells would be located on the same production well pad (see the drawing on the right below). The equipment on those pads would include water-steam separators, a large fluid holding pond (sump), and the insulated pipelines leading off to the power plant. CEE proposes to use a "flash technology" power plant with a condensing steam turbine and wet cooling tower. The generator and supporting equipment would be housed in a steel building with the cooling tower as a separate structure (see the drawing on the left above).

If the Pilot Project is approved, which could be in spring 1994, construction of the power production facilities could begin shortly thereafter. From the time construction begins, it would take 16 months or more before electricity is produced. (Source: Deschutes National Forest) 


\section{Nevada}

\section{Low-Temperature Geothermal Resources in Nevada}

The U.S. Department of Energy began a new geothermal energy program in Fiscal Year 1991. The objective of the program is to promote accelerated development of low- and moderate-temperature geothermal resources, and thus to offset fossil fuel use and improve the environment. The program has several components: collection of geothermal resource data, development of exploration techniques, technical assistance to potential geothermal developers, and evaluation of geothermal heat pump applications and use. An important aspect of several of the components is the evaluation of low- and moderate-temperature geothermal resources, especially in the western United States. participants in the program include the Geo-Heat center at the Oregon Institute of Technology (Klamath Falls), the University of Utah Research Institute, the Idaho Water Resources Research Institute (University of Idaho, Moscow), and agencies of state governments in most of the western states.

The Nevada Bureau of Mines and Geology (NBMG) has been selected as the agency in Nevada to participate in this geothermal program. NBMG will prepare an up-to-date inventory of the state's low- and moderate-temperature geothermal resources (from $10^{\circ} \mathrm{C}$ above mean annual temperature to $150^{\circ} \mathrm{C}$ ), and in cooperation with the Geo-Heat Center, analyze which of these resources are near population centers and thus more likely for development. This inventory will make use of the considerable geothermal resource data collected at NBMG in the late 1970 s and of new data from published and unpublished sources. Water chemistry data are available for many thermal springs and wells, and will be made a part of the database for the project. A few new analyses of thermal waters are planned as well. The project will utilize the extensive GIS (Geographic Information systems) capabilities available at NBMG to tabulate exact locations (map coordinates-for example, longitude and latitude) of all known thermal springs and wells.

A very important part of the data collection process is the identification of geothermal areas or sites which are relatively unknown or have not been previously described in published or otherwise readily available reports. Such sites would include warm or hot springs not shown on topographical maps or described in water resource reports, and areas of thermal groundwater encountered during drilling in areas not known to have geothermal resources. Additionally, NBMG needs more information on present uses of Nevada geothermal resources. Anyone who has information on new Nevada geothermal sites or uses should contact me at NBMG (702-784-6691). (Source: Nevada Bureau of Mines and Geology) 